\title{
NEMATODE POPULATION DYNAMICS AFTER APPLICATIONS OF PLANT EXTRACTS AND TRICHODERMA SPECIES AS SOIL AMENDMENTS IN TOMATO FIELD
}

\author{
aTimothy I. Olabiyi*, aSamuel 0. Akinrinola, bOlajumoke E. Ayanda \\ a Department of Crop and Environmental Protection, Ladoke Akintola University of Technology, Ogbomoso, Nigeria. \\ b Federal College of Animal Health and Production Technology, Department of Science Laboratory Technology (Biology \\ Unit), Moor Plantation, Ibadan, Nigeria.
}

\section{A R T I C L E I N F O}

\section{Article history}

Received: January 20, 2020

Revised: March 15, 2020

Accepted: April 18, 2020

\section{Keywords}

Trichoderma

Control

Nematode

Tomato

Bio-control

\section{A B S T R A C T}

Three different plant extracts (Khaya ivorensis, Azadirachta indica and Daniella oleifera) and two Trichoderma species (T. harzianum and T. atroviride), singly and in combination, were assessed on nematode population changes and also in the control of plant parasitic nematodes on tomato under field condition during 2018 and 2019 planting seasons. During each trial, plant parasitic nematodes encountered in the field were Meloidogyne, Pratylenchus, Xiphinema and Helicotylenchus species. The experiment was a randomized complete block design with $4 \times 3$ factorial scheme and five replications. Factor A being plant extracts (Khaya ivorensis, Azadirachta indica, Daniella oleifera) and control, and factor B being bio-control agents (Trichoderma harzianum, T. atroviride) and control, resulting in 12 treatments. Significant reductions were observed on the population of the plant parasitic nematodes at all treatment levels with neem plant extract, in combination with either T. harzianum or T. atroviride resulted in the greatest significant decrease. Applications of different plant extracts and Trichoderma species, singly and in combination, enhanced the growth and yield of tomato infected with parasitic nematodes.

Corresponding Author: Timothy I. Olabiyi

Email: tiolabiyi@lautech.edu.ng

(C) The Author(s) 2020.

\section{INTRODUCTION}

The production of tomato in tropical Africa covered a total area of about 300,000 ha with an estimated annual production of 2.3 million tonnes (Van der Vossen et al., 2004). Nigeria is the largest producer in tropical Africa with about 26,000 ha and yielding about 879,000 tonnes of fresh fruits annually (FAO, 2004). The fruit is rich in vitamins $\mathrm{A}, \mathrm{C}$, riboflavin, niacin and thiamine as well as some minerals like sodium and potassium (Janes, 2004). Tomatoes can grow well in many soil types, ranging from sandy loam to clay-loam. The soil types must be rich in organic matter with a pH range of 6-7 (Van der Vossen et al., 2004). The poor yield of tomato in Nigeria has been attributed to nematode diseases (Olabiyi, 2005 and Udo et al., 2008 and Ogwulumba et al., 2011).
Tomato plants infested with nematodes usually have galled roots and are very vulnerable to wilt and rotinducing pathogens (Williamson and Gleason, 2003).

Nematodes are notorious foes of virtually all economic crops; they cause tremendous damage to all crops. The nematodes are widespread agricultural pests found in all regions of the world. There is hardly any crop in the world which is free of nematode attacks (Agrios, 2005). Nematodes involve a reduction in quality and quantity of the crop. For sustainable tomato production, efforts must be made to obtain insights on the presence and distribution of nematode pests associated with major crops (Osei et al., 2012).

Nematode infestations on crops greatly have an impact on the health, quality and yield of the crop. Nematodes parasitize on a large number of plants and over 3000 
cultivated and uncultivated plant species are reported to be affected (Agrios, 2005). Nematodes are distributed world-wide over a wide range of geographical conditions of temperate, tropical and subtropical regions of the world. Nematodes are found to be the most abundant primitive multicellular animals on earth.

Numerically, nematodes are dominating organisms on earth and they are between 80 to $90 \%$ of all multicellular animals on earth maybe nematodes (Agrios, 2005). The major nematodes associated with tomato crops are Meloidogyne, Xiphinema, Rotylenchus, Pratylenchus, Helicotylenchus, Hoplolaimus (Agrios, 2005). The symptoms caused by these nematodes are stunting, yellowing of plants, lesions, root galls, patching of leaves etc. At the site of infection of Hoplolaimus species, many lateral roots may emerge giving the root system a bushy appearance (Jones et al., 2013). The most widespread and economically important nematodes are the root-knot nematodes (Meloidogyne spp.). Their life cycle can be completed in 25 days at $27^{\circ} \mathrm{C}$, but it can take longer at lower or higher temperatures. The short life cycle enables root-knot nematode population to survive in the presence of a suitable host and their population build up to a maximum as crops attain maturity. Root-knot nematodes infect a wide range of important crops and are particularly damaging the vegetable crops in tropical and subtropical areas of the world (Osman et al., 2012 and Youssef et al., 2012). The infested plants are stunted, chlorotic and unthrifty (Archana and Saxena, 2012). Among over hundreds described species of Meloidogyne, the four most commonly occurring species are Meloidogyne incognita, M. javanica, M. hapla, and M. arenaria. The species of root-knot nematode attack more than 2000 species of plants including almost all cultivated plants. Root-knot nematodes are reported to cause annual losses in tropics up to $29 \%$ in tomato, $24 \%$ in potato, $22 \%$ in okra, $23 \%$ in eggplant, $28 \%$ in beans and $25 \%$ in pepper (Williamson and Gleason, 2003).

Nematodes of the genus Xiphinema, commonly called dagger nematodes, parasitize plants. Many of these nematodes, the majority of which belonging to the Xiphinema americanum-group, can transmit viruses to plants during feeding (Gozel et al., 2006). It can cause economic damage and death of host crops through feeding on the roots and also by spreading wilting and viral mosaic diseases (Jones et al., 2013). Some species belonging to the Xiphinema americanum-group have been detected on tomato, pepper, oak, pines, hackberry and citrus (Mokrini et al., 2014). Other hosts include sorghum, cotton, turfgrass and pearl millet (Wick, 2012), sugarcane, legumes, banana, corn, sugar beet, chili pepper (Agrios, 2005), cassava, weeds (Rosa et al., 2014).

The most effective method of nematode disease control is the use of chemical nematicide. However, health hazards and the attendant adverse effects of chemical nematicides on the non-target organisms and the environment are serious constraints. Lately, alternative nematode management has been sought by many researchers to reverse this ugly trend. The exploitation of biological control methods for the integrated management of plant parasitic nematodes using antagonistic organisms is fast gaining wide acceptance in many countries (Hashem and Abo-Elyousr, 2011).

The application of Trichoderma species as bio-control agents and/or their metabolites for diseases control is one of the promising ways to reduce the farmers' reliance on synthetic chemicals in crop protection. Application of Trichoderma species or their metabolites had been reported to be one of the most effective bio-control biopesticides recommended for plant disease protection under organic agriculture (Izuogu et al., 2014). Trichoderma is listed both in Europe and USA as a biological pesticide permitted for use in organic farming. Trichoderma species have been known for a long period of time as registered commercial products and biological control agents for the control of plant diseases. Aside this is the potential of Trichoderma species to increase plant growth and development (Woo et al., 2006). Trichoderma species are known to involve in complex interactions with host plants and soil microbes (Ruocco et al., 2009). There are reports that some plant extracts contain some bio-nematicidal compounds that could be widely exploited in the control of plant parasitic nematodes (Olabiyi et al., 2011 and Olabiyi and Ayeni, 2016).

The objectives of this study are to assess the effects of Khaya ivorensis, Azadirachta indica, Daniella oleifera, Trichoderma harzianum and T. atroviride, singly and in combination, on the nematode population changes and also in the control of parasitic nematodes on tomato under the field condition.

\section{MATERIALS AND METHODS}

The experiments were conducted at Teaching and Research Farms, Ladoke Akintola University of Technology, Ogbomoso, Nigeria, $8.1227^{\circ} \mathrm{N}, 4.2436^{\circ} \mathrm{E}$, 
during 2018 and 2019 planting seasons. During each trial, the field was ploughed and harrowed thoroughly. The experimental field was divided into plots measuring $3.0 \mathrm{~m} \times 3.0 \mathrm{~m}$ with alleyways of $1.0 \mathrm{~m}$ in-between blocks and $1.5 \mathrm{~m}$ in-between plots. There were 16 plants per plot at a spacing of $75 \mathrm{~cm} \mathrm{x} 75 \mathrm{~cm}$ and $75 \mathrm{~cm}$ in-between the rolls. The experimental was a randomized complete block design with $4 \times 3$ factorial scheme and five replications. Factor A being plant extracts (Khaya ivorensis, Azadirachta indica, Daniella oleifera) and control, and factor B being biocontrol agents (Trichoderma harzianum, T. atroviride) and control, resulting in 12 treatments. The soil was sandy loam in all the treatments. One kilogram of each of the thoroughly washed and chopped stem bark of Khaya ivorensis, Azadirachta indica and Daniella oleifera were soaked separately in 1 liter of de-ionized water (Olabiyi and Ayeni, 2016). These were then centrifuged and filtered through Whatman No. 1 Filter Paper (Whatman, Bristol, UK).

Pure culture of Trichoderma harzianum and Trichoderma atroviride were obtained from spent Oyster mushroom substrate cultured on Potato Dextrose Agar in the Autoclave at 15 psi for 30 minutes in the laboratory (Baloyi et al., 2011). Identified pure culture of Meloidogyne, Pratylenchus, Xiphinema and Helicotylenchus species were obtained from National Horticultural Research Institute (NIHORT), Ibadan, Nigeria and Teaching and Research Farm, Ladoke Akintola University of Technology, Ogbomoso, Nigeria. Standardized aliquot quantity of $10 \mathrm{ml}$ distilled water containing 1000 juveniles of each nematode was used for the inoculation per plant using a band method.

Two weeks after planting tomato seedlings (Roma VF variety) of three weeks old, the treatments $(10 \mathrm{~mL}$ each of plant extract and $1 \times 10^{7}$ spores each of bio-control agents) were applied into the soil, either singly or in combination. The treatments were Khaya ivorensis, Khaya ivorensis + Trichoderma harzianum mixture, Khaya ivorensis + Trichoderma atroviride; Azadirachta indica, Azadirachta indica + Trichoderma harzianum, Azadirachta indica + Trichoderma atroviride, Daniella oleifera, Daniella oleifera + Trichoderma, Daniella oleifera + Trichoderma atroviride, Trichoderma harzianum, Trichoderma atroviride and control. Where neither plant extract nor bio-control was applied served as the control.
At planting, just before the application of soil treatment and at harvesting, soil and root samples were collected randomly from the experimental plots, three samples per plot, and the nematode populations in $200 \mathrm{~g}$ portions of soil and $10 \mathrm{~g}$ root sample were determined using the tray method of Whitehead and Hemming (1965). Nematodes are clarified, differentiated and identified to species level using C.I.H Nematodes description packages, of the sets 18 of CAB International UK (Luc et al., 1990). Soil and root nematode extractions, following Baermann tray method of Whitehead and Hemming (1965) and routine Physicochemical soil analysis, following method of Olabiyi et al. (2011) were done in the laboratory.

Data were collected on the population of plant parasitic nematodes, number of leaf, plant height, number of fruit and fruit weight per plant. Data collected were subjected to statistical analysis using Analysis of Variance and, where necessary, treatment means were separated with Duncan's multiple range tests.

\section{RESULTS}

The experimental soil contained coarse sand (45.0\%), fine sand $(31.0 \%)$, silt $(2.7 \%), \mathrm{pH}(6.7-6.8)$, Organic Carbon (9.5-9.6\%) and organic matter (16.4-16.6\%). The soil is classified as sandy loam. It was evident that the plant extracts and Trichoderma species, applied singly and in combination, reduced the populations of the plant parasitic nematode encountered (negative change), whereas there was a significant increase (positive change) in the population of plant parasitic nematodes in the control (where neither plant extracts nor Trichoderma species were applied (Table 1).

Percentage nematode change $=$ $\frac{\text { Pop. of nematode in } 2019-\text { Pop. of nematode in } 2018}{\text { Pop. of nematode in } 2018} \times 100$

The application of plant extracts and Trichoderma species singly and in combination, significantly $(\mathrm{p}<0.05)$ improved the plant growth (Table 2). The control had least plant height and number of leaves. The plant extract and Trichoderma species applied singly and in combination significantly enhanced the fruit number and weight of tomato from the plant parasitic nematodes. The control had the least plant growth (Table 3). 
Table 1. Effects of plant extracts and Trichoderma spices, singly and in combination, on the plant parasitic nematode populations dynamics.

\begin{tabular}{|c|c|c|c|c|c|c|c|c|c|c|c|c|}
\hline \multirow{2}{*}{ Treatments } & \multicolumn{3}{|c|}{ Meloidogyne species } & \multicolumn{3}{|c|}{ Pratylenchus species } & \multicolumn{3}{|c|}{ Xiphinema species } & \multicolumn{3}{|c|}{ Helicotylenchus species } \\
\hline & 2018 & 2019 & \% Change & 2018 & 2019 & \% Change & 2018 & 2019 & \% Change & 2018 & 2019 & \% Change \\
\hline Khaya ivorensis & $1,300 \mathrm{~b}$ & $1,100 a$ & $-15.4 \%$ & $151 b$ & $106 \mathrm{c}$ & $-29.8 \%$ & $48 b$ & $20 a$ & $-58.3 \%$ & $10 a$ & $4 a$ & $-60.0 \%$ \\
\hline K. ivorensis + T. harzanium & $1,628 c$ & $1,220 a$ & $-25.1 \%$ & $120 \mathrm{~b}$ & $102 c$ & $-15 \%$ & $52 b$ & $31 b$ & $-40.4 \%$ & $18 \mathrm{ab}$ & $6 a$ & $-66.7 \%$ \\
\hline K. ivorensis $+T$. atroviride & $1,432 b$ & $1,364 b$ & $-5.0 \%$ & $128 b$ & $100 c$ & $-21.9 \%$ & $40 \mathrm{ab}$ & $21 \mathrm{a}$ & $-47.5 \%$ & $15 a$ & $6 a$ & $-60.7 \%$ \\
\hline Azadirachta indica & $1,960 d$ & $1,136 \mathrm{ab}$ & $-42.0 \%$ & $94 a$ & $76 b$ & $-19.2 \%$ & $20 a$ & $12 \mathrm{a}$ & $-40.0 \%$ & $11 \mathrm{a}$ & $6 a$ & $-45.5 \%$ \\
\hline A. indica+ T. harzanium & $1,120 \mathrm{a}$ & $902 \mathrm{a}$ & $-19.5 \%$ & $56 a$ & $24 a$ & $-57.1 \%$ & $22 \mathrm{a}$ & $10 \mathrm{a}$ & $-54.5 \%$ & $10 \mathrm{a}$ & $4 a$ & $-60.0 \%$ \\
\hline A. indica + T. atroviride & $1,042 a$ & $886 a$ & $-15.0 \%$ & $88 a$ & $42 \mathrm{a}$ & $-52.3 \%$ & $22 \mathrm{a}$ & $12 \mathrm{a}$ & $-45.5 \%$ & $15 a$ & $7 a$ & $-53.3 \%$ \\
\hline Daniella oleifera & $2,486 \mathrm{e}$ & $1,447 \mathrm{c}$ & $-41.8 \%$ & $184 \mathrm{c}$ & $106 c$ & $-42.4 \%$ & $90 d$ & $38 b$ & $-57.8 \%$ & $22 b$ & $10 \mathrm{a}$ & $-54.5 \%$ \\
\hline D. oleifera $+T$. harzanium & $2,971 f$ & $1,872 \mathrm{~d}$ & $-37.0 \%$ & $192 \mathrm{c}$ & $106 c$ & $-44.8 \%$ & $72 \mathrm{c}$ & $48 c$ & $-33.3 \%$ & $15 a$ & $8 a$ & $-46.7 \%$ \\
\hline D. oleifera $+T$. atroviride & $3,500 \mathrm{~g}$ & $2,264 \mathrm{e}$ & $-35.3 \%$ & $245 d$ & $121 c$ & $-50.6 \%$ & $74 \mathrm{c}$ & $42 c$ & $-43.2 \%$ & $12 \mathrm{a}$ & $6 a$ & $-50.0 \%$ \\
\hline Trichoderma harzianum & $1,341 b$ & $956 a$ & $-28.7 \%$ & $128 b$ & $100 c$ & $-21.9 \%$ & $21 \mathrm{a}$ & $9 a$ & $-57.1 \%$ & $16 a$ & $9 a$ & $-43.8 \%$ \\
\hline Trichoderma atroviride & $1,428 b$ & $926 a$ & $-35.2 \%$ & $110 \mathrm{~b}$ & $104 c$ & $-5.5 \%$ & $22 \mathrm{a}$ & $10 \mathrm{a}$ & $-54.5 \%$ & $21 b$ & $7 a$ & $-66.7 \%$ \\
\hline Control & $6,898 \mathrm{~h}$ & $12,486 \mathrm{f}$ & $+81.0 \%$ & $950 \mathrm{e}$ & $1,084 \mathrm{~d}$ & $+14.1 \%$ & $1,084 \mathrm{e}$ & $760 \mathrm{~d}$ & $+36.7 \%$ & $387 c$ & $648 b$ & $+67.4 \%$ \\
\hline
\end{tabular}

Means followed by the same letters within the same column are not significantly different (Duncan test, $\mathrm{P}<0.05)$.

Table 2. Effect of plant extracts and Trichoderma species, singly and in combination, on the growth of tomato.

\begin{tabular}{|c|c|c|c|c|}
\hline \multirow[t]{2}{*}{ Treatment } & \multicolumn{2}{|c|}{ Plant height $(\mathrm{cm})$} & \multicolumn{2}{|c|}{ Number of leaves } \\
\hline & 2018 & 2019 & 2018 & 2019 \\
\hline Khaya ivorensis & $100.0 \mathrm{a}$ & $123.4 \mathrm{a}$ & $56 a$ & $62 \mathrm{a}$ \\
\hline K. ivorensis $+T$. harzianum & $77.0 \mathrm{bcd}$ & 83. 2c & $35 b$ & $44 c$ \\
\hline K. ivorensis $+T$. atroviride & $68.0 \mathrm{~cd}$ & $65.1 d$ & $35 d$ & $40 c$ \\
\hline Azadirachta indica & $80.0 \mathrm{bcd}$ & $86.9 c$ & $27 \mathrm{bc}$ & $32 \mathrm{~cd}$ \\
\hline A. indica + T. harzianum & $88.2 \mathrm{ab}$ & $96.4 \mathrm{bc}$ & $28 \mathrm{bc}$ & $36 \mathrm{~cd}$ \\
\hline A. indica $+T$. atroviride & 90. lab & $105.3 \mathrm{~b}$ & $30 b$ & $41 c$ \\
\hline Daniella oleifera & $74.2 \mathrm{bcd}$ & $68.5 c$ & $23 c$ & $20 \mathrm{~d}$ \\
\hline D. oleifera + T. harzianum & $85.46 \mathrm{ac}$ & $92.8 \mathrm{bc}$ & $25 \mathrm{bc}$ & $22 d$ \\
\hline D. oleifera $+T$. atroviride & $62.8 \mathrm{~d}$ & $77.7 \mathrm{~cd}$ & $28 \mathrm{bc}$ & $32 \mathrm{~cd}$ \\
\hline T. harzianum & $93.4 \mathrm{ab}$ & $116.8 \mathrm{~b}$ & $47 a b$ & $53 a b$ \\
\hline T. atroviride & $91.6 \mathrm{ab}$ & $114.6 \mathrm{~b}$ & $43 a b$ & $56 a b$ \\
\hline Control & $44.2 \mathrm{e}$ & $51.2 \mathrm{e}$ & $14 \mathrm{~d}$ & $18 \mathrm{e}$ \\
\hline S.E & 15.6 & 18.3 & 11.5 & 12.4 \\
\hline
\end{tabular}


Table 3. Effect of plant extracts and Trichoderma species, singly and in combination, on the yield of tomato.

\begin{tabular}{lcccc}
\hline Treatment & \multicolumn{2}{c}{ Number of fruits } & \multicolumn{2}{c}{ Fruit weight $(\mathrm{g})$} \\
\cline { 2 - 5 } & 2018 & 2019 & 2018 & 2019 \\
\hline Khaya ivorensis & $30 \mathrm{a}$ & $32 \mathrm{a}$ & $257.3 \mathrm{a}$ & $266 . \mathrm{la}$ \\
K. ivorensis + T. harzianum & $22 \mathrm{~b}$ & $24 \mathrm{~b}$ & $198.5 \mathrm{~b}$ & $200.7 \mathrm{~b}$ \\
K. ivorensis + T. atroviride & $19 \mathrm{bc}$ & $19 \mathrm{bc}$ & $118.8 \mathrm{c}$ & $148.7 \mathrm{c}$ \\
Azadirachta indica & $17 \mathrm{c}$ & $16 \mathrm{c}$ & $119.1 \mathrm{c}$ & $146.4 \mathrm{c}$ \\
A. indica + T. harzianum & $19 \mathrm{bc}$ & $20 \mathrm{bc}$ & $201.6 \mathrm{~b}$ & $206.8 \mathrm{~b}$ \\
A. indica + T. atroviride & $20 \mathrm{bc}$ & $23 \mathrm{~b}$ & $176.1 \mathrm{~b}$ & $181.5 \mathrm{~b}$ \\
Daniella oleifera & $18 \mathrm{bc}$ & $20 \mathrm{bc}$ & $170.1 \mathrm{~b}$ & $180.2 \mathrm{~b}$ \\
D. oleifera + T. harzianum & $19 \mathrm{bc}$ & $18 \mathrm{bc}$ & $204.9 \mathrm{~b}$ & $201.6 \mathrm{~b}$ \\
D. oleifera + T. atroviride & $15 \mathrm{~d}$ & $15 \mathrm{~d}$ & $132.8 \mathrm{c}$ & $181.4 \mathrm{~b}$ \\
T. harzianum & $23 \mathrm{~b}$ & $28 \mathrm{~b}$ & $200.4 \mathrm{~b}$ & $203.5 \mathrm{~b}$ \\
T. atroviride & $21 \mathrm{bc}$ & $26 \mathrm{~b}$ & $199.6 \mathrm{~b}$ & $198.4 \mathrm{~b}$ \\
Control & $8 \mathrm{e}$ & $10 \mathrm{e}$ & $72.7 \mathrm{~d}$ & $68.9 \mathrm{~d}$ \\
S.E & 3.75 & 4.21 & 28.26 & 30.46 \\
\hline
\end{tabular}

\section{DISCUSSION}

The fields were inoculated and the nematode population dynamics, in 2018 and 2019 planting seasons, just after the application of some plant extracts and Trichoderma species as soil amendments in tomato field, were established. The results revealed that plant extracts and Trichoderma species that were applied singly and in combination significantly suppressed the soil nematode population build-up and also enhanced the growth and yield of tomato.

Various researches have shown that Trichoderma may improve plant establishment, enhance root growth, protect against soil and waterborne pathogens and hence decrease root diseases (Young et al., 2002 and Baloyi et al., 2011). Trichoderma is capable of producing secondary metabolites with antibiotic activity. Of recent, Trichoderma composted hardwood bark isolates, was reported to produce a metabolite (Harzianic acid) with antifungal and plant growthpromoting activity. Trichoderma species have been formulated and used as bio-pesticides, bio-protectants, bio-stimulants and bio-fertilizer on a large variety of crops (Vinale et al., 2009 and Izuogu et al., 2014). As a today, Trichoderma-based bio-fungicides are realities in agriculture, with more than 50 registered formulations worldwide. The use of organic amendments had been suggested (Olabiyi and Oladeji, 2014) and recommendation made for the use of plant extracts to control nematodes (Olabiyi and Ayeni, 2016).

The current research established Meloidogyne, Pratylenchus, Xiphinema and Helicotylenchus species, are threats to tomato production in Nigeria. The growth and yield of Tomato grown in nematode infested soil were significantly reduced. This was evident on tomato plants that were treated with plant extracts and Trichoderma species and those that were not treated. Root knot nematodes, Meloidogyne species (of the family: Heteroderidae) for instance, present great threats to food crop production worldwide (Lopez-Perez et al., 2011). In addition to reducing yields, they cause unpleasant, unappealing, and warty appearances on tubers of yam and related species, and root knot symptoms on the root of susceptible crops (Olabiyi et al., 2013).

\section{CONCLUSION}

Applications of different plant extracts and Trichoderma species, singly and in combination, enhanced the growth and yield of tomato infected with parasitic nematodes. It becomes imperative therefore to find out the nematicidal properties of the plant extracts and Trichoderma species during the further study.

\section{REFERENCES}

Agrios, G. N. 2005. Plant Pathology Elsevier Academic Press: New York, USA.

Archana, B. and R. Saxena. 2012. Nematicidal effect of root extract of certain medicinal plants in control of $\mathrm{J} 2$ of Meloidogyne incognita in vitro and in vivo conditions. Pakistan Journal of Nematology, 30: 179-87.

Baloyi, M. A., M. D. Laing and K. S. Yobo. 2011. Isolation 
and in vitro screening of Bacillus thuringiensis and Clonostachys rosea as biological control agents against sheep nematodes. African Journal of Agricultural Research, 6: 5047-54.

FAO. 2004. Food and Agriculture Organization of the United Nation. Production Year Book. Rome, Italy. pp. 526.

Gozel, U., K. Nguyen, L. Rosso, L. Duncan, B. Adams, A. Agostinelli and F. Lamberti. 2006. Molecular and morphological consilience in the characterisation and delimitation of five nematode species from Florida belonging to the Xiphinema americanumgroup. Nematology, 8: 521-32.

Hashem, M. and K. A. Abo-Elyousr. 2011. Management of the root-knot nematode Meloidogyne incognita on tomato with combinations of different biocontrol organisms. Crop Protection, 30: 285-92.

Izuogu, N. B., O. V. Osuwa, A. O. Fabiyi, T. I. Olabiyi and S. A. Abolusoro. 2014. Field evaluation of Trichoderma harzianum T22 for the management of Meloidogyne incognita (kofoid and white) Chitwood on cowpea varieties. International Journal of Agricultural Sciences and Natural Resources, 1: 7-12.

Janes, H. W. 2004. Tomato production in protected cultivation. Encyclopedia of Agricultural Sciences, 4: 337-49.

Jones, J. T., A. Haegeman, E. G. J. Danchin, H. S. Gaur, J. Helder, M. G. K. Jones, T. Kikuchi, R. ManzanillaLópez, J. E. Palomares-Rius, W. M. L. Wesemael and R. N. Perry. 2013. Top 10 plant-parasitic nematodes in molecular plant pathology. Molecular Plant Pathology, 14: 946-61.

Lopez-Perez, J. A., S. Edwards and A. Ploeg. 2011. Control of root-knot nematodes on tomato in stone wool substrate with biological nematicides. Journal of nematology, 43: 110-17.

Luc, M., R. A. Sikora and J. Bridge. 1990. Plant Parasitic Nematodes in Subtropical and Tropical Agriculture CAB International Wallingford, U.K.

Mokrini, F., F. A. Andaloussi, L. Waeyenberge, N. Viaene and M. Moens. 2014. First report of the dagger nematode Xiphinema diversicaudatum in citrus orchards in Morocco. Plant Disease, 98: 575-75.

Ogwulumba, S., K. Ugwuoke and R. Ogbuji. 2011. Reaction of tomato cv. roma vf (Solanum Lycopersicum) to Meloidogyne Javanica treub infestation in an ultisol treated with aqueous leaf extracts of bitter leaf (Vernonia Amygdalina L.) and mango (Mangifera Indica L.). Journal of Plant Protection Research, 51: 14-17.

Olabiyi, T. and 0. 0. Oladeji. 2014. Assessment of four compost types on the nematode population dynamics in the soil sown with okra. International Journal of Organic Agriculture Research and Development, 9: 146-55.

Olabiyi, T. I. 2005. Application of plant materials in the control of nematode pests of tomato in rural areas of Nigeria: A Case Study. Afro Asian Journal of Rural Development, 33: 49-55.

Olabiyi, T. I., I. O. Adepoju, S. A. Abolusoro and E. E. A. Oyedunmade. 2011. Supprssion of nematode pests of tomato with aqueous leaf extracts of nitta, tobacco and pawpaw. American-Eurasian Journal of Agronomy, 4: 23-27.

Olabiyi, T. I. and B. P. Ayeni. 2016. Assessment of Azadirachta indica and Cleome viscosa liquidformulations as bio-nematicides in the management of nematode pests of okra. African Journal of Agricultural Research, 11: 467-71.

Olabiyi, T. I., T. A. Ogunniran, O. J. Ojo, J. J. Atungwu and S. A. Abolusoro. 2013. Efficacy of wild sunflower compost on root lesion nematode, pest of maize. Indian Journal of Nematology, 43: 29-33.

Osei, K., M. K. Osei, M. B. Mochiah, J. N. L. Lamptey, G. Bolfrey-Arku and J. N. Berchie. 2012. Plant parasitic nematodes associated with tomato in Ghana. Nematologia Mediterranea, 40: 33-37.

Osman, H. A., M. M. A. Youssef, A. Y. El-Gindi, H. H. Ameen, N. A. Abd-Elbary and A. M. S. Lashein. 2012. Effect of salicylic acid and Pseudomonas fluorescens against Meloidogyne incognita in eggplant using split-root technique. Pakistan Journal of Nematology, 30: 101-13.

Rosa, J. M. O., S. A. d. Oliveira, A. L. Jordão, A. Siviero and C. M. G. d. Oliveira. 2014. Plant parasitic nematodes on cassava cultivated in the Brazilian Amazon. Acta Amazonica, 44: 271-75.

Ruocco, M., S. Lanzuise, F. Vinale, R. Marra, D. Turrà, S. L. Woo and M. Lorito. 2009. Identification of a new biocontrol gene in Trichoderma atroviride: The role of an $\mathrm{ABC}$ transporter membrane pump in the interaction with different plant-pathogenic fungi. Molecular Plant-Microbe Interactions, 22: 291-301.

Udo, I. A., M. I. Uguru, R. O. Ogbuji and D. A. Ukeh. 2008. 
Sources of tolerance to root-knot nematode, Meloidogyne javanica, in cultivated and wild tomato species. Plant Pathology Journal, 7: 40-44.

Van der Vossen, H. A. M., R. Non-Wondim and C. M. Messian. 2004. Lycopersicon esculentum Mill. In: G. J. H. Grubben and O. A. Denton (eds.), Plant Resources of Tropical Africa PROTA Foundation Backhuys Publishers: Netherlands.

Vinale, F., G. Flematti, K. Sivasithamparam, M. Lorito, R. Marra, B. W. Skelton and E. L. Ghisalberti. 2009. Harzianic acid, an antifungal and plant growth promoting metabolite from Trichoderma harzianum. Journal of Natural Products, 72: 2032-35.

Whitehead, A. G. and J. R. Hemming. 1965. A comparison of some quantitative methods of extracting small vermiform nematodes from soil. Annals of Applied Biology, 55: 25-38.

Wick, R. 2012. Nematodes on golf greens. Agriculture and Landscape ProgramThe Center for Agriculture, Food and the Environment, University of Massachusetts. Amherst.

Williamson, V. M. and C. A. Gleason. 2003. Plantnematode interactions. Current Opinion in Plant Biology, 6: 327-33.

Woo, S. L., F. Scala, M. Ruocco and M. Lorito. 2006. The molecular biology of the interactions between Trichoderma spp., phytopathogenic fungi, and plants. Phytopathology, 96: 181-85.

Young, E. T., N. Kacherovsky and K. Van Riper. 2002. Snf1 protein kinase regulates Adr1 binding to chromatin but not transcription activation. Journal of Biological Chemistry, 277: 38095-103.

Youssef, M. M. A., M. M. M. Mohammed and A. M. Korayam. 2012. Effect of organic and inorganic fertilizers on Meloidogyne incognita infesting sugar beet. Pakistan Journal of Nematology, 30: 143-49.

\section{CONFLICT OF INTEREST}

The authors declare that they have no conflicts of interest.

\section{AUTHORS CONTRIBUTIONS}

All the authors contributed equally to this work.

Publisher's note: EScience Press remains neutral with regard to jurisdictional claims in published maps and institutional affiliations.

Open Access This article is licensed under a Creative Commons Attribution 4.0 International License, which permits use, sharing, adaptation, distribution and reproduction in any medium or format, as long as you give appropriate credit to the original author(s) and the source, provide a link to the Creative Commons license and indicate if changes were made. The images or other third-party material in this article are included in the article's Creative Commons license, unless indicated otherwise in a credit line to the material. If material is not included in the article's Creative Commons license and your intended use is not permitted by statutory regulation or exceeds the permitted use, you will need to obtain permission directly from the copyright holder. To view a copy of this license, visit http://creativecommons.org/licenses/by/4.0/. 